\title{
EPIDEMIOLOGY OF ADULT FRACTURES IN EASTERN CROATIA BY CAUSE OF INJURY, FRACTURE LOCATION AND TYPE OF TREATMENT
}

\author{
Roman Pavić ${ }^{1,2}$, Dijana Hnatešen ${ }^{1,3}$ and Petra Margetić ${ }^{2}$
}

${ }^{1}$ School of Medicine, Josip Juraj Strossmayer University of Osijek, Osijek; ${ }^{2}$ Clinical Department of Traumatology, Sestre milosrdnice University Hospital Center, Zagreb, Croatia; ${ }^{3}$ Osijek University Hospital Center, Osijek, Croatia

\begin{abstract}
SUMMARY - This retrospective study investigated the impact of age on fracture occurrence through the comparison of two patient groups, 17-64 and 64+ age groups. Study data covered all fractures treated at a large hospital in eastern Croatia. A total of 15,519 patients with fractures were treated at the trauma department (inpatient and outpatient), with a total of 17,257 fractures presented, $71 \%$ managed as outpatients and $29 \%$ as inpatients. A total of 11,046 outpatients were treated for 12,187 fractures and a total of 4473 inpatients were treated for 5070 fractures. The group of 17-64-year old males had 5787 fractures, accounting for $34 \%$ of all fractures presented. The group of 17-64-year old females had 4094 fractures, accounting for $24 \%$ of total fractures. The group of $65+$ year-old males had 2659 fractures, accounting for $15 \%$ of all fractures presented and the group of $65+$ year-old females presented with 4717 fractures, accounting for $27 \%$ of all fractures presented. The 'fall in level' was the predominant cause of injury in all patients. The characteristics of osteoporotic bone fractures were evident in the population of $65+$ females and to a lesser degree in $65+$ males. The 17-64 age group, both males and females, had more fractures considered as high-energy fractures.
\end{abstract}

Key words: Retrospective studies; Inpatients; Outpatients; Accidental falls; Osteoporotic fractures; Croatia

\section{Introduction}

Over years, lifespan has increased and the number of fractures associated with old age has increased with the general population aging. As early as 1832, Ashley Cooper recognized the effects of aging on the skeleton $^{1}$, and in 1882 Bruns wrote about the influence of age and gender on the incidence of various types of fracture $^{2}$. Osteoporosis and osteoporotic fractures (also known as minimal-trauma, age-related, or low-energy fractures) are a major, continuously increasing public health problem worldwide, especially in high standard

Correspondence to: Prof. Roman Pavić, MD, PhD, Clinical Department of Traumatology, Department of Hand Surgery, Sestre milosrdnice University Hospital Center, Draškovićeva 19, HR-10000 Zagreb, Croatia

E-mail: romanpavic29@gmail.com

Received June 27, 2016, accepted December 21, 2016 societies with aging populations ${ }^{3-5}$. Buhr and Cooke were the first to publish a classic paper on fracture epidemiology in $1959^{6}$, and a number of studies have been undertaken since then ${ }^{7-13}$. Typical sites of osteoporotic fractures are distal forearm, vertebral, proximal and distal humerus, ankle, knee, hip, pelvis, and ribs ${ }^{3,13-22}$. Hip fractures, the most serious of osteoporotic injuries, are associated with more deaths, impairment, disability and costs than all other osteoporotic fractures combined $^{22-26}$. The exact reasons for the increasing agespecific incidence of osteoporotic fractures in older adults are largely unknown. A common view is that the increase in the incidence of age-related bone loss or osteoporosis could be one of the most important factors implicated ${ }^{27-29}$, but convincing evidence regarding any secular trend in age-adjusted bone strength of older adults is lacking. On the other hand, the incidence of fall-induced injuries sustained by frail older 
persons is increasing ${ }^{30,31}$ and many recent investigations have shown that falls and associated risk factors are even more important predictors of fractures than osteoporosis. In order to discover the prevalent fractures in our elderly population versus adult working age population in our geographical area, we conducted a retrospective study of all fractures treated at the region's largest hospital.

\section{Patients and Methods}

We observed 15,519 patients treated for fractures over a 5-year period, from January 1, 2009 to December 31, 2013. There were 7580 males and 7939 females included. To be included, patients had to be aged $17+$ and treated for at least one fracture, with or without other injuries. Head trauma was not included because they were always referred to a different service within the hospital. The included fracture treated patients were divided into two age groups, as follows: 9263 patients aged 17-64 and 6256 patients aged $65+$. All study patients were observed in total and subdivided into the groups treated as outpatients or inpatients. They were also processed according to gender, cause of injury, and fracture location. A total of 17,257 fractures were presented. The cause of injury was reported by the patient and grouped with similar causes. The inpatients of the 17-64 and 65+ age groups were compared according to conservative or surgical treatment and length of hospital stay. All study patients were from the geographical area of eastern Croatia.

Statistical analysis was performed using Statistica 12 software; $\chi^{2}$-test was used on group comparison, and binomial test was employed when the values were too small to use $\chi^{2}$-test. The level of statistical significance was set at $\mathrm{p}<0.05$.

\section{Results}

Data on 15,519 patients were observed during the 2009-2013 period. These patients were divided according to age groups and mode of management (inpatient or outpatient). Figure 1a shows data on the 17-64 age group outpatients and inpatients and 65+ age group outpatients and inpatients treated over the 5 -year period. Figure $1 \mathrm{~b}$ shows total number of fractures according to year and age group. The total number of fractures was 17,257.

We found no statistically significant difference in the total number of male and female patients. Of the total of 15,519 patients, there were 7580 males and 7939 females. There was no significant difference in the outpatients according to gender and groups (Fig. 2). However, there was a significant gender difference in the 17-64 group, with more males in the inpatient 17-64 age group and more females in the inpatient $65+$ age group $(\mathrm{p}<0.05$ both).

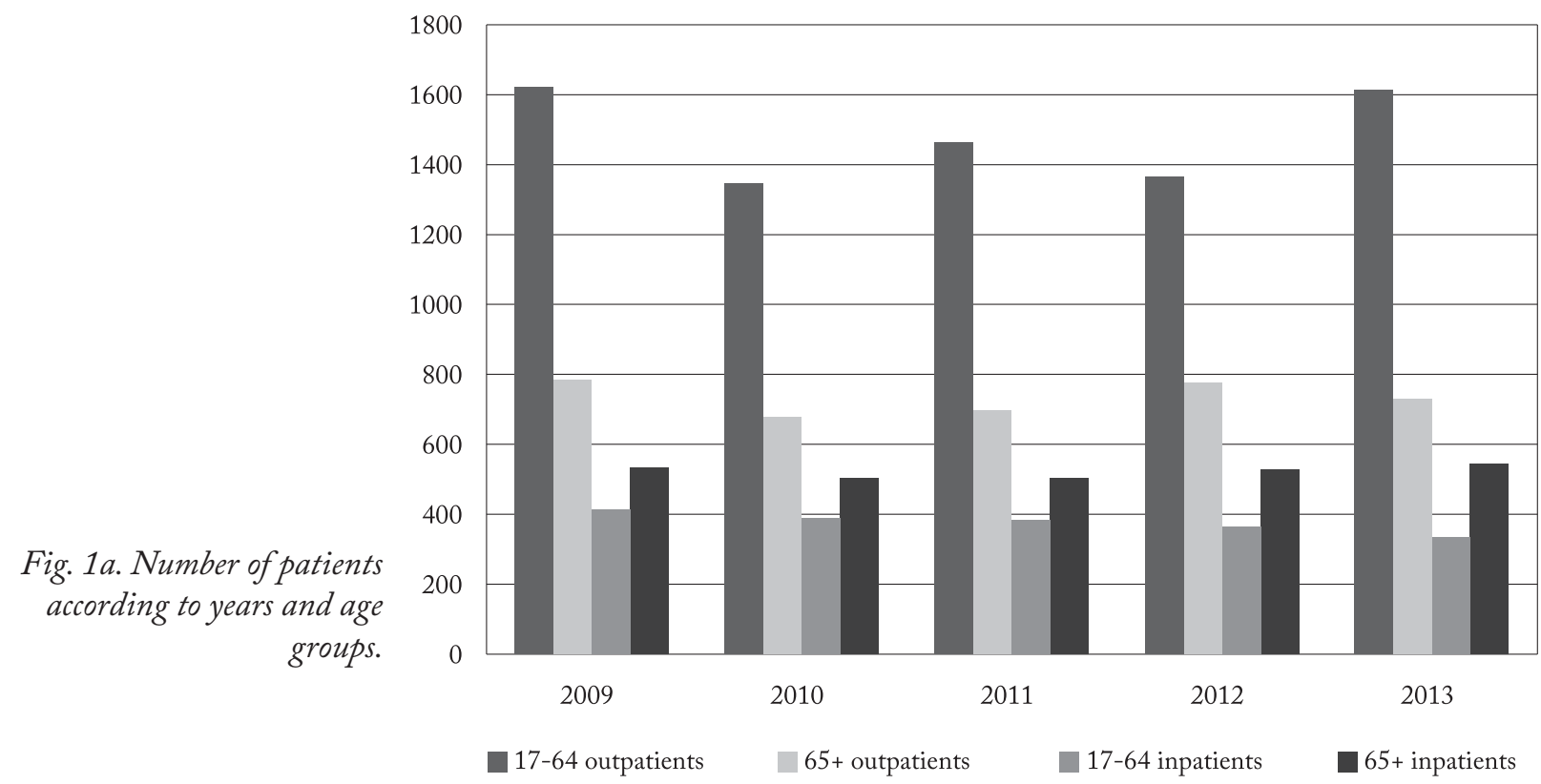




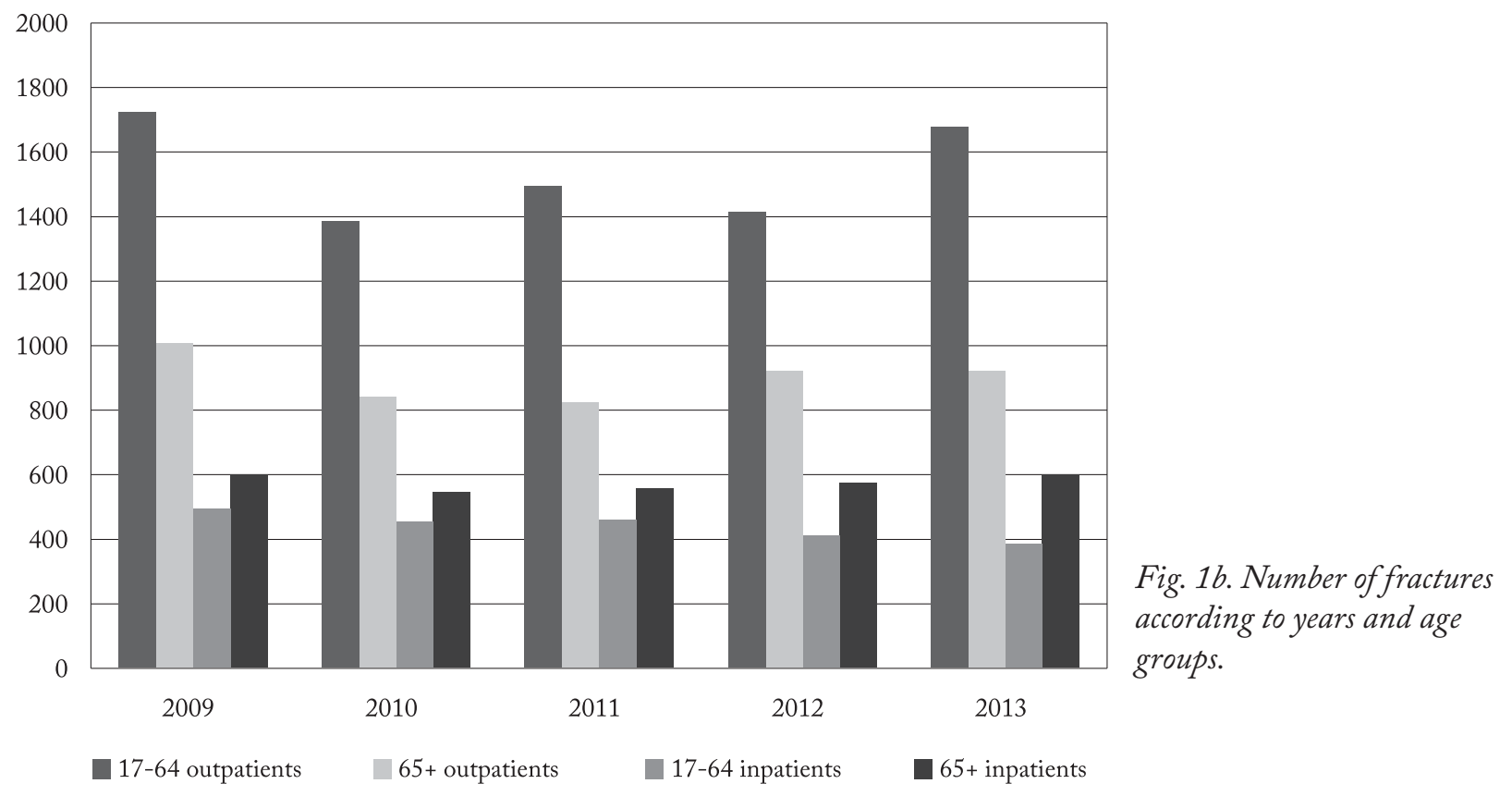

Figures $3 \mathrm{a}$ and $3 \mathrm{~b}$ show the cause of injury in outpatients and inpatients divided into 17-64 and 65+ age groups. The total number of outpatients was 11,046 and of inpatients 4473. In all groups, the majority of injuries were caused by the 'fall in level'.

A total of 17,257 fractures were presented by 15,519 patients treated (Fig. 4a and 4b). A total of 12,187 fractures were treated on an outpatient basis, of which 7681 fractures in the 17-64 age group and 4506 fractures in the $65+$ age group. A total of 5070 fractures were treated on an inpatient basis, of which 2200 in the 17-64 age group and 2870 in the $65+$ age group. Fractures treated in males aged 17-64 accounted for $34 \%$ of total fractures, those in males aged $65+$ for $15 \%$, whereas fractures treated in females aged 17-64 accounted for $24 \%$ and those in females aged $65+$ for $27 \%$ of cases.

There were 2200 patients aged 17-64 and slightly more patients aged $65+(n=2870)$ treated as inpatients. There was no significant difference in conservative and operative fracture treatment according to age groups (Fig. 5).

The total number of inpatients treated was 4473 patients, including 1869 patients in the 17-64 age group and 2604 patients in the $65+$ age group. The length of hospital stay was divided into groups of 'up to 7 days', '8-14 days', '15-21 days', and '22 days or more'. There was no significant difference in the length

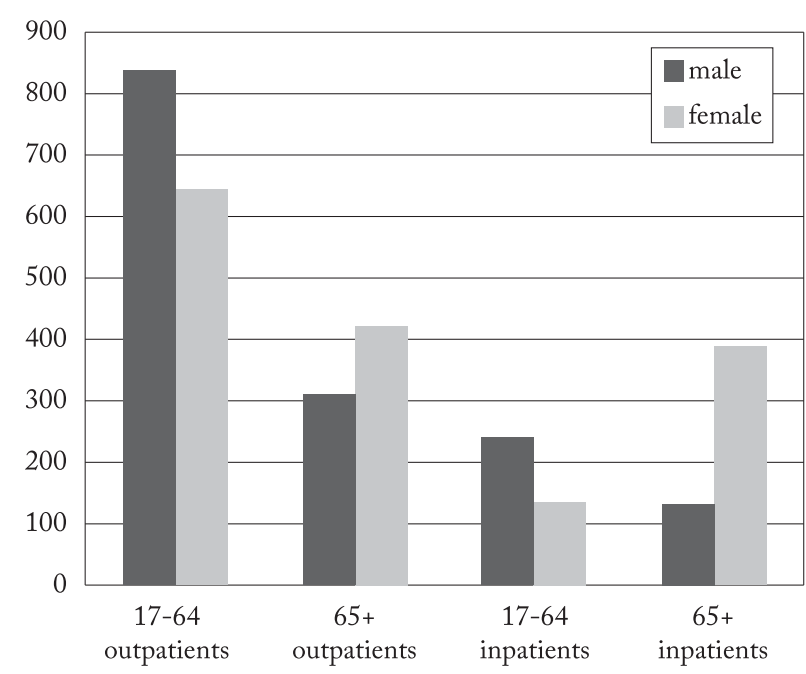

Fig. 2. Average total patients according to sex and age groups.

of hospital stay according to age groups (Fig. 6a and $6 b)$.

\section{Discussion}

In this study, we investigated the impact of age on fracture occurrence. We compared two groups of injured patients, i.e. a group of active individuals aged 17-64 and a group of individuals aged 65+ at the time of retirement. Our study covered the geographical area 
Fig. 3a. Cause of injury in 17-64 age group by hospitalization.
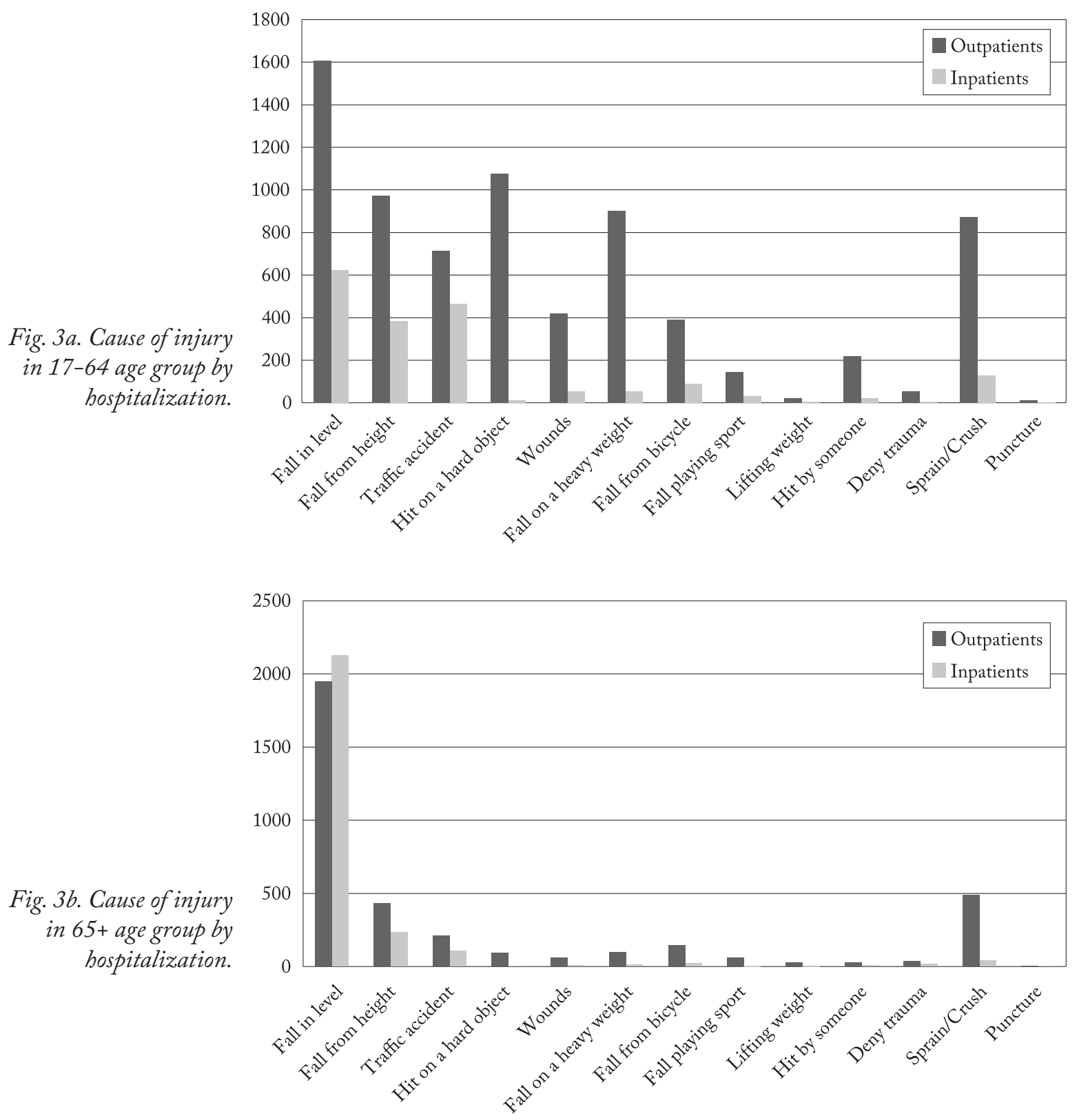

of eastern Croatian and included the largest body of data related to age, sex, cause of injury, fracture location, outpatient clinic or hospital treatment ever done on this area. In the literature, there are several reports related to particular geographical areas, but usually include only one type of fracture. Some papers report on the incidence of fractures in the elderly from particular geographic areas ${ }^{13,26,32}$, and we did so in the present study as well, however, we included complete adult population (aged $\geq 17$ years) of the study area. Epidemiological studies carried out geographically closest to our geographical region were those conducted in Hungary $^{33}$ and Austria ${ }^{34}$, but primarily related to hip fracture.

In England, fracture incidence is 3.6 fractures per 100 people per year. The lifetime fracture prevalence exceeds $50 \%$ in middle-aged men and $40 \%$ in women over age 75 . Males had a significantly higher fracture prevalence than females in every age group except for $>75$ age group, where women prevailed ${ }^{35}$. Because a hospital's catchment population is not a reliable denominator for descriptive epidemiological study ${ }^{32,35}$, in 


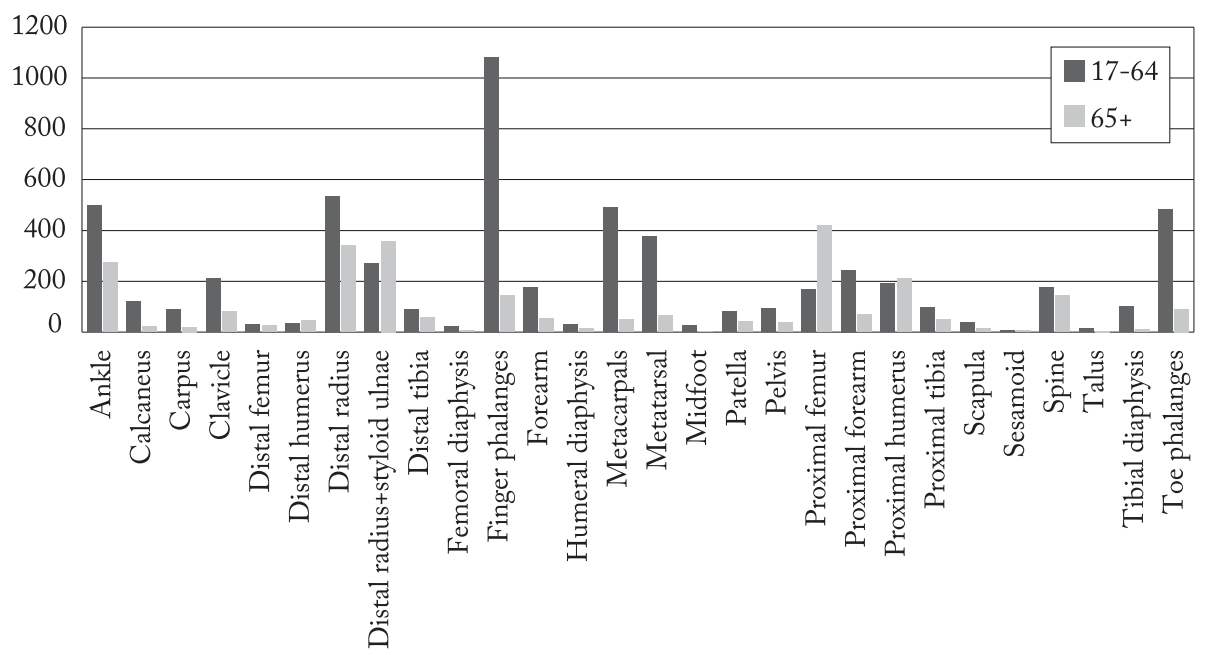

Fig. 4a. Number of fractures diagnosed in male patients according to age groups.

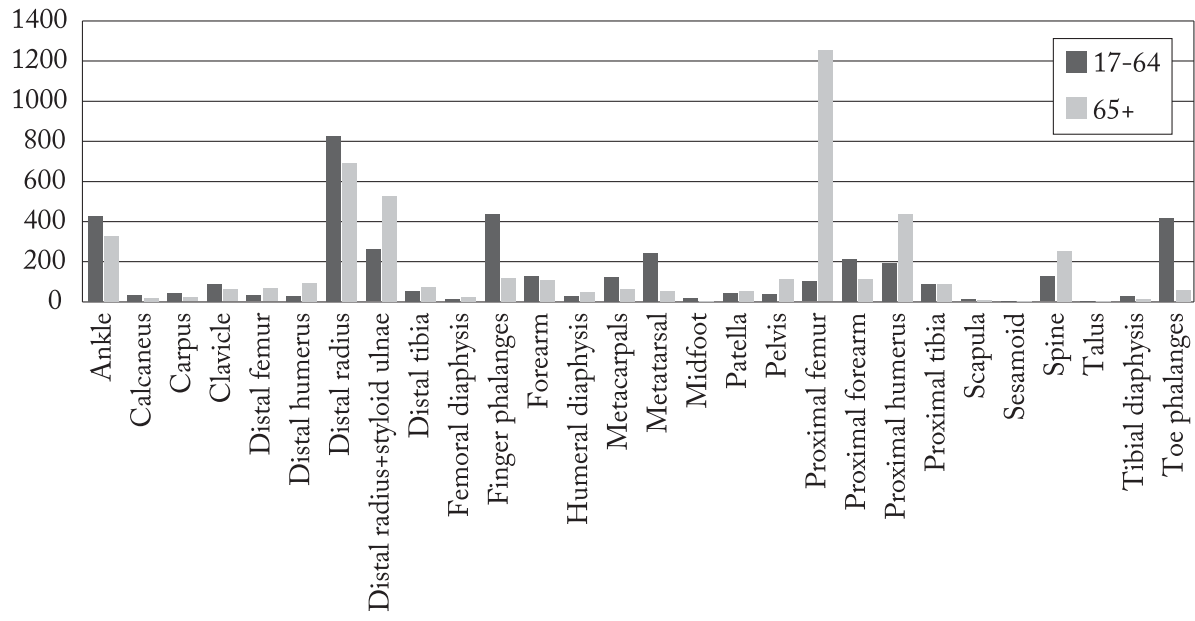

Fig. 4b. Number of fractures diagnosed in female patients according to age groups.

our epidemiological study we looked at all treated fractures, including both inpatients and outpatients. The nearest geographical studies to our study were conducted in Hungary, focused exclusively on hip fractures $^{33,36}$. The age adjusted incidence of hip fractures in Hungary was 430/100,000 in women and 223/100,000 in men $^{33,36}$. In the nearby Austria, the incidence of hip fracture is from $471 / 100,000$ to $567 / 100,000$ per year in men and from $637 / 100,000$ to $759 / 100,000$ per year in women ${ }^{34}$.

We collected data on all patients treated at a large hospital in eastern Croatia during a 5-year period. The overall number of patients with fractures treated at trauma department (inpatient and outpatient) was 15,519 patients with a total of 17,257 fractures (Fig. $1 \mathrm{a}$ and $1 \mathrm{~b})$. Of the 17,257 fractures presented in the 5 -year period, $71 \%$ were managed as outpatients and

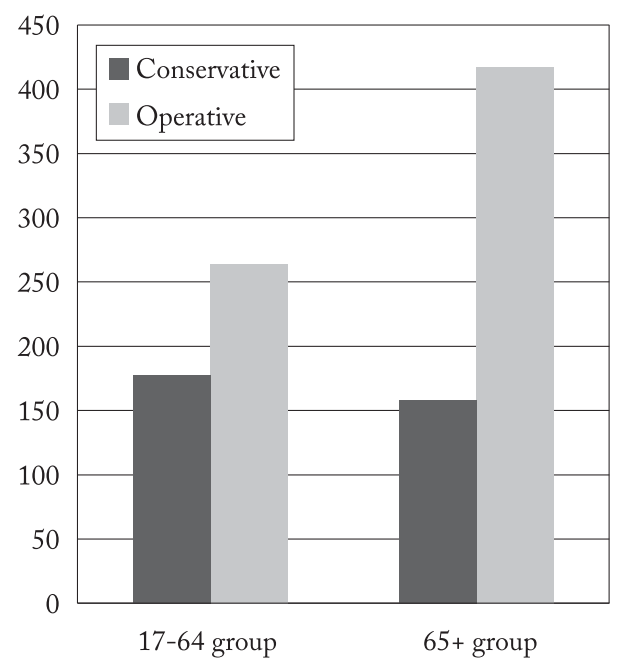

Fig. 5. Fracture treatment (conservative versus operative) in 17-64 and 65+ age groups. 


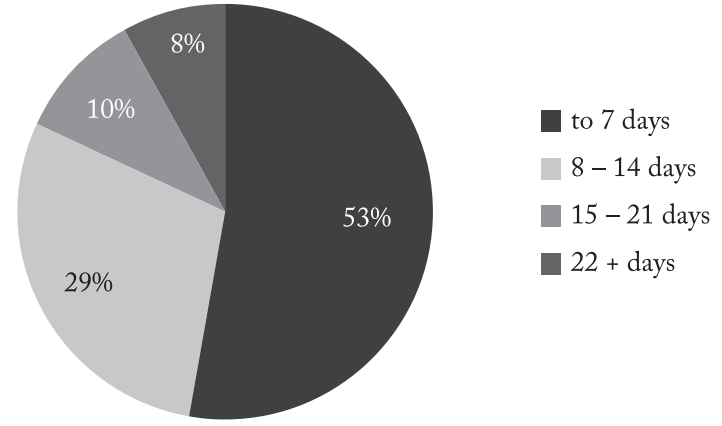

Fig. 6a. Average hospitalization in 17-64 age group.

$29 \%$ as inpatients. A total of 11,046 outpatients were treated for 12,187 fractures, $67 \%$ of them in the $17-64$ age group. A total of 4473 inpatients were treated for 5070 fractures, $58 \%$ of them in the $65+$ age group. The group of males aged 17-64 had 5787 fractures or 34\% of all fractures presented. The group of females aged 17-64 had 4094 fractures or $24 \%$ of total fractures. The group of males aged $65+$ had 2659 fractures or $15 \%$ of all fractures presented, while the group of females aged $65+$ had 4717 fractures or $27 \%$ of all fractures presented. Looking only at these percentages, it is obvious that the females aged $65+$ had almost twice as many fractures as the males aged $65+$, as expected due to the prevalence of osteoporosis in female population.

Osteoporosis is a bone disease characterized by low bone mass and microarchitectural deterioration of bone tissue leading to enhanced bone fragility and a consequent increase in fracture risk ${ }^{37}$. Characteristics of the osteoporosis bone fractures are that their number and incidence increases sharply with age, they are more common in women than in men, they occur at the sites that contain substantial amounts of trabecular bone, and they are associated with minimal or moderate trauma only $y^{4,53}$. Figure 2 summarizes data on the male and female patients according to age and mode of treatment (outpatient or inpatient). There was no significance regarding gender and fractures. Comparing age groups and patient treatment, significantly more female patients aged 17-64 were treated as outpatients than inpatients $(\mathrm{p}<0.05)$. However, comparison of male patients revealed that there were significantly more males aged 17-64 than those aged $65+$ in the inpatient group $(\mathrm{p}<0.05)$. Significantly more females aged $65+$ with fractures were treated as inpatients $(p<0.05)$, while no significant difference was recorded in the outpatients aged $65+$.

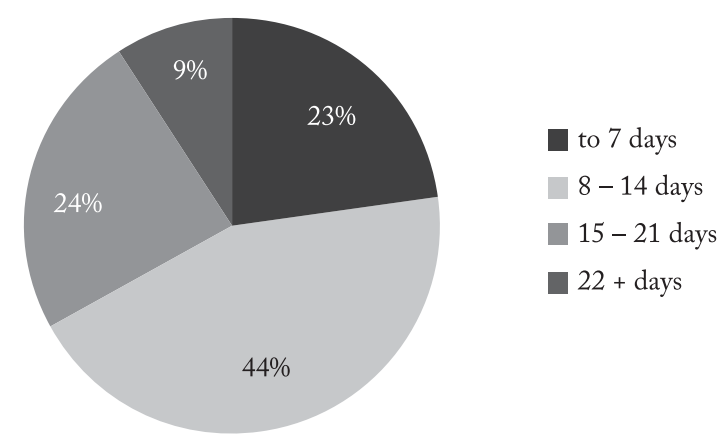

Fig. 6b. Average hospitalization in $65+$ age group.

About $70 \%-80 \%$ of all osteoporotic fractures, except for vertebral fractures, and over $90 \%$ of osteoporotic hip and upper extremity fractures are the result of a fall ${ }^{25,39}$. According to the literature, "... a fall also includes a descent phase, an impact phase and a post impact phase during which the subject comes to rest" $" 40,41$. Very little is known about these later phases of falling or fall mechanics, however, osteoporotic fractures frequently require only low energy to occur. Figures 3a and $3 \mathrm{~b}$ show that 'fall in level' was the predominant cause of injury in all patients. In outpatients, 'fall in level'was the most frequent cause of injury in both age groups, i.e. 1603 (22\%) in the 17-64 age group and 1946 (53\%) in the 65+ age group. In the 17-64 age group, the next most prevalent causes of injury were recorded in similar percentages: 'hit on a hard object' $15 \%$, 'fall from height' $13 \%$, 'fall of weight' $12 \%$, and 'sprain/crush' $12 \%$. In the $65+$ age group, the next most prevalent causes were 'sprain/crush' $13 \%$ and 'fall from height' $12 \%$. The most frequent cause of injury in inpatients aged 17-64 was 'fall in level' 33\%, followed by 'traffic accident' $25 \%$ and 'fall from height' $20 \%$. In the inpatients aged $65+$, the most frequent cause of injury was 'fall in level' $82 \%$, followed by 'fall from height' $9 \%$ and 'traffic accident' $4 \%$.

In the literature, falling is a less predominant cause of vertebral fractures than of hip fractures, although $25 \%-50 \%$ of acute symptomatic vertebral fractures among older adults are related to falls and controlled activities such as lifting ${ }^{42-44}$. Most hip fractures are the result of falling ${ }^{45-47}$, but only about $1 \%$ of falls among older women result in hip fractures ${ }^{48}$. Falling is much more likely to cause hip fracture if the subject falls sideways and lands on or near the greater trochanter, if the fall has high impact energy (as initiated from a greater height), if the person does not land on or use 
hand to diminish the energy of the fall, and if the person lands on a hard rather than soft surface ${ }^{47,49-51}$. Wrist fractures are closely associated with falling onto an outstretched arm, which may explain why their incidence (in the literature) does not increase significantly after the age of 60 , when people become more sedentary and unable to use their arms to reduce the falling energy ${ }^{35}$. However, sideways falls are unlikely to result in wrist fractures ${ }^{4,50}$, while falling backwards on an outstretched arm with the wrist hyperextended may in many cases be the cause of wrist fracture ${ }^{50}$. In the USA, $71 \%$ of fractures of the distal forearm occurred as a result of a fall from standing height or less $^{36}$, in Norway this figure reaches $81 \%{ }^{52}$, and in Denmark $87 \%$ in women and $64 \%$ in men $^{53}$.

In our study (Fig. 4a and 4b), we investigated specific fractures presented to either outpatient or inpatient care. In patients presenting to outpatient care, the five most frequent fractures (with corresponding percentage in the respective age group) involved the following sites: 1) distal radius 2235 patients (17\% in 1764 age group and $21 \%$ in $65+$ age group); 2) finger phalanges 1711 patients (19\% in 17-64 age group and $6 \%$ in $65+$ age group); 3 ) distal radius with styloid ulnea 1350 patients (7\% in 17-64 age group and 19\% in 65+ age group); 4) ankle 1206 patients (9\% in 17-64 age group and $11 \%$ in $65+$ age group); and 5) toe phalanges 1039 patients (85\% in 17-64 age group and $15 \%$ in $65+$ age group). The five most frequent fractures presenting to inpatient care (with corresponding percentage in the respective age group) involved the following sites: 1) proximal femur 1903 patients (12\% in $17-64$ age group and $57 \%$ in $65+$ age group); 2 ) spine 418 patients (10\% in 17-64 age group and 7\% in $65+$ age group); 3 ) proximal humerus 316 patients (5\% in 17-64 age group and 7\% in 65+ age group); 4) ankle 314 patients (11\% in 17-64 age group and 3\% in 65+ age group); and 5) pelvis 259 patients (47\% in 17-64 age group and $53 \%$ in $65+$ age group).

According to literature data, almost $80 \%$ of the fractures of proximal humerus in people aged $\geq 18$ years are the result of a fall ${ }^{54}$. In elderly women, the figure is even $95 \%{ }^{25}$. About $75 \%$ of falls leading to fracture of proximal humerus occur from standing height or less in women aged 65 and older ${ }^{36}$. These fractures come more easily in individuals who walk slowly, fall sideways, and are not able to slow down the fall with an outstretched arm. The orientation of the fall and the site of impact are presumably of significance in determining the type of fracture that will result from the fall. In the Introduction, we explained the most common sites of osteoporotic fractures. About $52 \%$ of fractures in general should be considered potentially osteoporotic ${ }^{13}$. In men, $30.1 \%$ of fractures are potentially osteoporotic compared with $66.3 \%$ of fractures in women. In addition, $34.7 \%$ of outpatient and $70.4 \%$ of inpatient fractures are potentially osteoporotic $^{13}$. Social conditions and medical treatment have led to an increasing population aging with an increasing number of fractures in both men and women. The fact that the incidence of fractures in elderly men is only about half the incidence in women agrees with our data. Our overall number of males aged $65+(2659$ patients) was just above half the overall number of age-matched females (4717 patients).

Hip fractures increase from the age of 65 years. There are three interacting factors related to hip fractures: bone strength, the risk of falling, and the efficiency of neuromuscular responses that protect the skeleton in the 50-74 age group ${ }^{55}$. Reduced bone mass was found to be a strong independent risk factor for hip fracture, but over age 75 , and osteoporosis may be less important than impairment to the protective neuromuscular response ${ }^{56}$. Differences between women older than 45 and men, especially in fractures of the diaphysis and metaphysis of long bones, may be partially due to menopausal osteoporotic fractures ${ }^{56}$. In our study (Fig. 4a and 4b), the fractures typically viewed as osteoporotic were seen at a higher percentage in the group of females aged 65+ than in other groups. Females from the $65+$ age group had the highest percentage of the following fractures: distal femur (44\%), distal humerus (45\%), distal radius + styloid ulnae (37\%), distal tibia (27\%), femoral diaphysis (38\%), humeral diaphysis (38\%), pelvis (40\%), proximal femur (64\%), proximal humerus (42\%), and spine $(36 \%)$.

Males from the $65+$ age group had a higher incidence of the following fractures: distal humerus (22\%), distal radius + styloid ulnae (25\%), proximal femur (22\%), and proximal humerus (20\%), but did not surpass the percentages of these fractures in the females aged $65+$. In comparison to age-matched females, the males aged $65+$ had more fractures of calcaneus $(13 \%$ vs. $9 \%)$, clavicle (18\% vs. $13 \%)$, and scapula $(18 \%$ vs. $12 \%)$. 
In our study, 1206 and 314 ankle fractures were treated on an outpatient and inpatient basis, respectively. In both outpatients and inpatients, a greater proportion of fractures occurred in younger patients (age $17-64$ ), i.e. $61 \%$ (33\% in males and $28 \%$ in females). Eighteen percent of total fractures occurred in males aged $65+$ and $21 \%$ in females aged $65+$. In this study, we commented how ankle fractures have been determined as osteoporotic in the literature, and we found that the numbers were not indicative of osteoporosis, although it could not be ruled out as the cause in the elderly group. Fractures of the patella were treated in the hospital in 98 cases, while 126 cases were treated as outpatients. The number of fractures was comparable in the two age groups, i.e. outpatient $55 \%$ to $45 \%$ and inpatient $58 \%$ to $42 \%$. Patella fractures occurred in 35\% of males aged $17-64,25 \%$ of females aged $65+, 21 \%$ of females aged $17-64$, and $19 \%$ males aged $65+$. Fractures of the pelvis were treated at the hospital in 259 cases, while 27 cases were treated as outpatients. The number of fractures was slightly higher in the older groups of patients (age $65+$ ), i.e. $63 \%$ of outpatients and $53 \%$ of inpatients. Pelvis fracture occurred in $40 \%$ of females aged $65+, 33 \%$ of males aged $17-64,14 \%$ of females aged $17-64$, and $13 \%$ of males aged $65+$.

Fractures of the proximal tibia were treated in 175 cases as outpatients, while 153 cases were treated as inpatients. Among outpatients, this fracture was more common (66\%) in older group of patients (age 65+), while inpatient treatment was more common (73\%) in younger group (age 17-64). Proximal tibia fractures occurred in $30 \%$ of males aged $17-64,28 \%$ of females aged $17-64,27 \%$ of females aged $65+$, and $15 \%$ of males aged $65+$.

Fractures of the spine were treated in 418 inpatient cases. In this group, there was a slightly higher incidence of these fractures (52\%) in younger group of $\mathrm{pa}^{-}$ tients (age 17-64). There were 293 fractures of the spine treated as outpatients. More than two-thirds (69\%) of spinal fractures treated on an outpatient basis were in the group of elderly (age 65+) patients. Spinal fractures occurred in $36 \%$ of females aged $65+, 25 \%$ of males aged $17-64,21 \%$ of males aged $65+$, and $18 \%$ of females aged 17-64. The 17-64 and 65+ age groups differed according to the cause of spinal fracture.

In our study, the male 17-64 age group had the highest percentages of the following fractures: calcaneus (59\%), carpus (50\%), clavicle (47\%), distal tibia (32\%), femoral diaphysis (35\%), finger phalanges (60\%), forearm (38\%), metacarpals (67\%), metatarsals (51\%), midfoot $(50 \%)$, patella $(35 \%)$, proximal forearm $(38 \%)$, scapula (51\%), sesamoid (100\%), talus (65\%), tibial diaphysis (65\%), and toe phalanges (46\%). The female $17-$ 64 age group only exceeded other groups in distal radius fractures $(35 \%)$ but shared many fractures with the male 17-64 age group, just at lower percentages: calcaneus (19\%), carpus $(26 \%)$, clavicle (21\%), finger phalanges (25\%), forearm (28\%), humeral diaphysis (23\%), midfoot (40\%), proximal forearm (33\%), talus (35\%), and toe phalanges (40\%). The fractures seen in both male and female 17-64 age groups are more active injuries ${ }^{57}$, mostly tied to traffic accidents or sports injuries ${ }^{58}$.

The results presented in Figure 5 show the inpatient treatment used for fractures sustained. There is no surprise that the majority were treated operatively. There were slightly more patients aged $65+$ admitted to the hospital but not significantly, i.e. 2200 and 2870 inpatients aged 17-64 and 65+, respectively. All outpatients were treated conservatively. Over the 5-year period of observation, the ratio of conservative versus operative treatment, and even the total number of $\mathrm{pa}-$ tients aged $17-64$ or $65+$ remained similar, with no significant differences.

In the inpatients aged 17-64 (Fig. 6a), the most frequent length of hospital stay was 7 days, while other lengths of hospital stay were less frequent. The inpatients aged $65+$ (Fig. 6b) were mostly hospitalized for 8-14 days, closely followed by hospital stay of up to 7 days and 15-21 days. A significantly lower number of patients were hospitalized for more than 22 days. The length of hospital stay remained rather consistent throughout the 5-year period of observation.

To our knowledge, this was the largest study of fracture epidemiology undertaken in this region. During five years, we observed consistency in the numbers of patients treated for fractures. The characteristics of osteoporotic bone fractures, associated with minimal or moderate trauma, were evident in the population of females aged $65+$ and to a lesser extent in males aged $65+$. The fractures prevalent in the population aged $17-$ 64 , both male and female, were high-energy fractures.

\section{References}

1. Cooper AP. Treatise on dislocations and on fractures of the joints: fractures of the neck of the thigh bone. Clin Orthop. 1973;92:3-5. doi: 10.1097/00003086-197305000-00002 
2. Alfframm PA, Bauer GCH. Epidemiology of fractures of the forearm: a biomechanical investigation of bone strength. J Bone Joint Surg (Am). 1962;44-A:105-14.

3. Cummings SR, Kelsey JL, Nevitt MC, O’Dowd KJ. Epidemiology of osteoporosis and osteoporotic fractures. Epidemiol Rev. 1985;7:178-208.

4. Riggs BL, Melton J $3^{\text {rd }}$. Osteoporosis: Etiology, Diagnosis and Management: Epidemiology of Fractures. New York: Raven Press; 1988.

5. Jones G, Nguyen T, Sambrook PN, Kelly PJ, Gilbert C, Eisman JA. Symptomatic fracture incidence in elderly men and women: the Dubbo Osteoporosis Epidemiology Study (DOES). Osteoporosis Int. 1994;4:277-82. doi: 10.1007/BF01623352

6. Buhr AJ, Cooke AM. Fracture patterns. Lancet. 1959;1:531-6. doi: 10.1016/S0140-6736(59)92306-2

7. Donaldson LJ, Cook A, Thomson RG. Incidence of fractures in a geographically defined population. J Epidemiol Community Health. 1990;44:241-5. doi: 10.1136/jech.44.3.241

8. Fife D, Barancik J. Northeastern Ohio trauma study. III. Incidence of fractures. Ann Emerg Med. 1985;14:244-8. doi: 10.1016/S0196-0644(85)80448-0

9. Johansen A, Evans RJ, Stone MD, Richmond PW, Lo SV, Woodhouse KW. Fracture incidence in England and Wales: a study based on the population of Cardiff. Injury. 1997;28: 655-60. doi: 10.1016/S0020-1383(97)00144-7

10. Sahlin Y. Occurrence of fractures in a defined population; a 1-year study. Injury. 1990;21:158-60. doi: 10.1016/00201383(90)90084-8, 10.1016/0020-1383(90)90085-9

11. Singer BR, McLauchlin GL, Robinson CM, Christie J. Epidemiology of fractures in 15,000 adults: the influence of age and gender. J Bone Joint Surg (Br). 1998;80:243-8. doi: 10.1302/ 0301-620X.80B2.7762

12. van Staa TP, Dennison EM, Leufkens HG, Cooper C. Epidemiology of fractures in England and Wales. Bone. 2001;29: 517-22. doi: 10.1016/S8756-3282(01)00614-7

13. Court-Brown CM, Caesar B. Epidemiology of adult fractures: a review. Injury. 2006;37:691-7. doi: 10.1016/j.injury.2006.04.130

14. Johnston CC, Slemenda CW. Pathogenesis of osteoporosis. Bone. 1995;17(Suppl):S19-S22. doi: 10.1016/8756-3282(95) 00202-O

15. Sambrook PN. Osteoporosis. Med J Australia. 1996;165:332-6.

16. Darabos N, Bajs ID, Sabalić S, Pavić R, Darabos A, Cengić T. Elements for successful functional result after surgical treatment of intra-articular distal humeral fractures. Acta Clin Croat. 2012;51(4):627-31.

17. Pavić R, Margetić P. Emergency treatment for clinically unstable patients with pelvic fracture and haemorrhage. Coll Antropol. 2012;36(4):1445-52.

18. Pavić R, Malović M. Isolated capitellum humeri fractures in adults. Coll Antropol. 2012;36(1):187-94.

19. Pavic R, Court-Brown CM, Clement N. Four score years and ten; an analysis of the epidemiology of fractures in the very el- derly [Injury 2009;40(Oct (10)):1111-4]. Injury. 2011;42(2): 224. doi: 10.1016/j.injury.2009.12.007

20. Pavic R. PFNA for unstable proximal femoral fractures. Injury. 2010;41(9):974-5. doi: 10.1016/j.injury.2009.07.005

21. Pavic R. Comments on "Surgical management of neglected fractures of the patella" [Injury 2007;38:979-83]. Injury. 2008;39(7):821-2. doi: 10.1016/j.injury.2008.02.019

22. Has B, Nagy A, Has-Schön E, Pavić R, Kristek J, Splavski B. Influence of instability and muscular weakness in etiopathogenesis of hip fractures. Coll Antropol. 2006;30(4):823-7.

23. Phillips S, Fox N, Jacobs J, Wright W. The direct medical costs of osteoporosis for American women aged 45 and older. Bone. 1988;9:271-9. doi: 10.1016/8756-3282(88)90009-9

24. Chrischilles EA, Butler CD, Davis CS, Wallace RB. A model of lifetime osteoporosis impact. Arch Intern Med. 1991; 151:2026-32. doi: 10.1001/archinte.151.10.2026, 10.1001/ archinte.1991.00400100100017

25. Nevitt MC. Epidemiology of osteoporosis. Rheum Dis Clin North Am. 1994;20:535-59.

26. Court-Brown CM, Clement N. Four score years and ten; an analysis of the epidemiology of fractures in the very elderly. Injury. 2009;40:1111-4. doi: 10.1016/j.injury.2009.06.011

27. Wasnich RD, Ross PD, Heilbrun LK, Vogel JM. Selection of the optimal skeletal site for fracture risk prediction. Clin Orthop. 1987;216:262-9. doi: 10.1097/00003086-198703000-00040

28. Melton LJ III, Atkinson EJ, O'Fallon WM, Wahner HW, Riggs BL. Long-term fracture prediction by bone mineral assessed at different skeletal sites. J Bone Miner Res. 1993;8: 1227-33. doi: 10.1002/jbmr.5650081010

29. Johnell O, Gullberg B, Kanis JA, Allander E, Elffors L, Dequekers J, et al. Risk factors for hip fracture in European women: the MEDOS study. J Bone Miner Res. 1995;10:1802-15. doi: 10.1002/jbmr.5650101125

30. Rubenstein LZ, Josephson KR, Robbins AS. Falls in the nursing home. Ann Intern Med. 1994;121:442-51. doi: 10.7326/ 0003-4819-121-6-199409150-00009

31. Kannus P, Parkkari J, Koskinen S, Niemi S, Palvanen M, Järvinen $\mathrm{M}$, et al. Fall-induced injuries and deaths among older adults. JAMA. 1999;281:1895-9. doi: 10.1001/jama.281.20.1895

32. Donaldson LJ, Reckless IP, Scholes S, Mindell JS, Shelton NJ. The epidemiology of fractures in England. J Epidemiol Community Health. 2008;62:174-80. doi: 10.1136/jech.2006.056622

33. Pentek M, Horvath C, Bonez I, Falusi Z, Toth E, Sebestyen A, et al. Epidemiology of osteoporosis related fractures in Hungary from the nationwide health insurance database, 19992003. Osteopor Int. 2008;19:243-9. doi: 10.1007/s00198-007-0453-6

34. Mann E, Icks A, Haastert B, Meyer G. Hip fracture incidence in the elderly in Austria: an epidemiological study covering the years 1994 to 2006. BMC Geriatr. 2008;8:35. doi: 10.1186/ 1471-2318-8-35

35. Rungby J, Hermann AP, Mosekilde L. Epidemiology of osteoporosis. Drugs Aging. 1995;6:470-8. doi: 10.2165/00002512199506060-00007 
36. Kelsey JL, Browner WS, Seeley DG, Nevitt MC, Cummings SR. Risk factors for fractures of the distal forearm and proximal humerus. Am J Epidemiol. 1992;135:477-89.

37. Melton LJ $3^{\text {rd }}$. Epidemiology of fractures. In: Orwell ES, editor. Osteoporosis in Men. The Effects of Gender on Skeletal Health. San Diego: Academic Press; 1999. doi: 10.1016/b978012528640-4/50002-2

38. Kannus P, Parkkari J, Sievänen H, Heinonen A, Vuori I, Järvinen M. Epidemiology of hip fractures. Bone. 1996;18(Suppl): 57-63. doi: 10.1016/8756-3282(95)00381-9

39. Cummings SR. Treatable and untreatable risk factors for hip fracture. Bone. 1996;18(3 Suppl):165S-167S. doi: 10.1016/ 8756-3282(95)00505-6

40. Hayes WC, Myers ER, Morris JN, Gerhart TN, Yett HS, Lipsitz LA. Impact near the hip dominates fracture risk in elderly nursing home residents who fall. Calcif Tissue Int. 1993;52: 192-8. doi: 10.1007/BF00298717

41. Hayes WC, Myers ER, Robinovitch SN, Van Den Kroonenberg A, Courtney AC, McMahon TA. Etiology and prevention of age-related hip fractures. Bone. 1996;18(1) Suppl:77-86. doi: 10.1016/8756-3282(95)00383-5

42. Cooper C, Atkinson EJ, O'Fallon WM, Melton LJ. Incidence of clinically diagnosed vertebral fractures: a population-based study in Rochester, Minnesota, 1985-1989. J Bone Miner Res. 1992;7:221-7. doi: 10.1002/jbmr.5650070214

43. Myers ER, Wilson SE, Greenspan SL. Vertebral fractures in the elderly occur with falling and bending. J Bone Miner Res. 1996;11(Suppl):S355.

44. Meyers ER, Wilson SE. Biomechanics of osteoporosis and vertebral fractures. Spine. 1997;22(Suppl):25S-31S. doi: 10.1097/ 00007632-199712151-00005

45. Alffram PA. An epidemiological study of cervical and trochanteric fractures of the femur in an urban population. Acta Orthop Scand. 1964;65(Suppl):1-109. doi: 10.3109/ort.1964.35. suppl-65.01

46. Johnell O, Obrant KJ. Halka bakomliggande orsak till trefaldig ökning av radius och fotledsfrakturer. Läkartidningen. 1983; 41:3777. (in Swedish)

47. Parkkari J, Kannus P, Palvanen M, Natri A, Vainio J, Aho H, et al. Majority of hip fractures occur as a result of a fall and impact on the greater trochanter of the femur: a prospective controlled hip fracture study with 206 consecutive patients. Calcif Tissue Int. 1999;65:183-7. doi: 10.1007/s002239900679

48. Nevitt M, Cummings SR. Falls and fractures in older women. In: Vellas B, Toupet M, Rubenstein L, Albarede J, Christen Y, editors. Falls, Balance and Gait Disorders in the Elderly. Paris: Elsevier, 1992; p. 69-80.

49. Grisso JA, Kelsey JL, Strom BL, Chiu GY, Maislin G, O’Brien LA, et al. Risk factors for falls as a cause of hip fracture in women. N Engl J Med. 1991;324:1326-31. doi: 10.1056/ NEJM199105093241905

50. Nevitt MC, Cummings SR. Type of fall and risk of hip and wrist fractures: the study of osteoporotic fractures. JAGS. 1993;41:1226-34. doi: 10.1111/j.1532-5415.1993.tb07307.x

51. Greenspan SL, Myers ER, Maitland LA, Resnick NM, Hayes WC. Fall severity and bone mineral density as risk factors for hip fracture in ambulatory elderly. JAMA. 1994;271:128-33. doi: 10.1001/jama.1994.03510260060029, 10.1001/jama.271.2.128

52. Hove LM, Fjeldsgaard K, Reitan R, Skjeie R, Sörensen FK. Fractures of the distal radius in a Norwegian city. Scand J Plast Reconst Hand Surg. 1995;29:263-7. doi: 10.3109/02844319 509050137

53. Solgaard, Petersen VS. Epidemiology of distal radius fractures. Acta Orthop Scand. 1985;56:391-3. doi: 10.3109/17453678 508994354, 10.3109/17453678508993006

54. Lind T, Krøner K, Jensen J. The epidemiology of fractures of the proximal humerus. Arch Orthop Trauma Surg. 1989;108: 285-7. doi: 10.1007/BF00932316

55. Cooper C, Barker DJP, Morris J, Briggs RSJ. Osteoporosis, falls and age in fracture of the proximal femur. Br Med J. 1987; 295:13-5. doi: 10.1136/bmj.295.6589.13, 10.1136/bmj.295. 6595.445-a

56. Singer BR, McLauchlan GJ, Robinson CM, Christie J. Epidemiology of fractures in 15000 adults. J Bone Joint Surg. 1998; 80-B:243-8. doi: 10.1302/0301-620X.80B2.7762

57. Pavić R. Talocalcaneal transfixation in total dislocation of the talus and subtalar dislocations. Mil Med. 2009;174(3):324-7. doi: 10.7205/MILMED-D-00-8408

58. Pavic R. Comment on: „Displaced intra-articular calcaneal fractures: 15-year follow-up of a randomised controlled trial of conservative versus operative treatment" [Injury 2007;38: 848-55]. Injury. 2008;39(3):380; author reply 380. doi: 10.1016/ j.injury.2007.10.025 
Sažetak

\section{EPIDEMIOLOGIJA PRIJELOMA KOSTI U ODRASLOJ DOBI PREMA UZROKU OZLJEDE, LOKACIJI PRIJELOMA I VRSTI LIJEČENJA U ISTOČNOJ HRVATSKOJ}

\section{R. Pavié, D. Hnatešen i P. Margetić}

U ovoj retrospektivnoj studiji procijenjena je ovisnost prijeloma kosti o dobi ispitanika kroz usporedbu dviju skupina bolesnika u dobi od 17-64 i 65+ godina. Svi bolesnici su liječeni na traumatološkom odjelu najveće bolnice u istočnoj Hrvatskoj, stacionarno ili ambulantno. Ukupan broj bolesnika bio je 15.519 sa 17.257 prijeloma. Prema načinu liječenja $71 \%$ bolesnika liječeno je ambulantno, a 29\% stacionarno; 11.046 ambulantnih bolesnika su liječeni zbog 12.187 prijeloma, dok su 4473 stacionarna bolesnika liječeni zbog 5070 prijeloma. Skupina bolesnika muškog spola u dobi od 17-64 godine imala je 5787 prijeloma, tj. 34\% od ukupnog broja prijeloma. Skupina bolesnica u dobi od 17-64 godine imala je 4094 prijeloma, tj. 24\% od ukupnih prijeloma. Muškarci stariji od 65 godina su imali 9717 prijeloma ili 27\% od ukupnih prijeloma. "Pad u razini” bio je najčešći uzrok ozljeđivanja. Osteoporotski prijelomi bili su češći u skupini žena starijih od 65 godina nego kod muškaraca iste dobi. Prijelomi u populaciji u dobi od 17-64 godine kod oba spola bili su obilježeni kao ozljeda visoke energije.

Ključne riječi: Retrospektivne studije; Ambulantni bolesnici; Hospitalizirani bolesnici; Nesretni pad; Osteoporotski prijelomi; Hrvatska 